\title{
Erratum
}

\section{Correction to Dinić, Bulut Allred, Petrović, and Wertag (2020)}

In the article entitled "A test of three sadism measures: Short sadistic impulse scale, varieties of sadistic tendencies, and assessment of sadistic personality" by Bojana M. Dinić, Tara Bulut Allred, Boban Petrović, and Anja Wertag (Journal of Individual Differences, https://doi.org/10.1027/ 1614-0001/a000319) the acknowledgments are missing. They should read as follows:

\section{Acknowledgments}

This research was partially supported by the Ministry of Education, Science and Technological Development of the Republic of Serbia [Grant No. 179006]. The authors would like to thank Goran Knežević for his significant contribution to the back translation of the VAST and Ashley
Lauren Watts for providing the procedure for calculating the $D$ statistic.

The authors regret any inconvenience or confusion this error may have caused.

\section{Reference}

Dinić, B. M., Bulut Allred, T., Petrović, B., \& Wertag, A. (2020). A test of three sadism measures: Short sadistic impulse scale, varieties of sadistic tendencies, and assessment of sadistic personality. Journal of Individual Differences. Advance online publication. https://doi.org/10.1027/1614-0001/a000319

Published online May 13, 2020 